\title{
Żeby ośmielić się tworzyć trzeba mieć odwagę myślenia. Czyli ikonografia prof. Jerzego Nowosielskiego jako wyraz świadomości religijnej
}

\author{
Tomasz Tarasiuk \\ Instytut Sztuki w Warszawie Polskiej Akademii Nauk \\ Polska \\ tarasiuk.tomasz@gazeta.pl
}

\begin{abstract}
Tomasz Tarasiuk, The courage to reflect is the bravery to create. The iconography of prof. Jerzy Nowosielski as an expression of religious consciousness, Elpis, 19 2017: 107-112.

Abstract: This paper synthesizes the content that accurately and clearly reveals the essence of the sacred image commonly known as an icon. Professor Nowosielski has translated this content - that stems directly from the Tradition of the Orthodox Church and vivid religious experience - into contemporary, comprehensible language. This text shows that the novelty in the iconographic art is not merely a result of contemplation and a creatively justified artistic vision, a matter of allegiance or craft, but it is solely a combination of religious enlightenment and artistic inspiration. It proves that the canon in the icon is not understood as an external framework but as the core through which the icon exists as a work of art - the text of the Church's faith shown on the soil of personal mystical experience and iconographer talent.

\begin{abstract}
Streszczenie: Praca ta, to synteza treści, które trafnie i prosto ujawnią nam zawartość obrazu sakralnego powszechnie nazywanego dziś ikoną. Treści te wypływają bezpośrednio z Tradycji Kościoła prawosławnego i żywego doświadczenia religijnego, a profesor tłumaczy je nam współczesnym, jakże zrozumiałym językiem. Tekst pokazuje, że nowość w sztuce ikonograficznej nie jest jedynie owocem kontemplacji oraz twórczo uzasadnionej wizji artystycznej, sprawą alegoryzmu lub rzemiosła, ale również połączeniem religijnego oświecenia oraz artystycznego natchnienia. Dowodzi, że kanon w ikonie nie jest rozumiany jako zewnętrzne ramy, ale jako rdzeń, dzięki któremu ikona istnieje jako dzieło sztuki - tekst wiary Kościoła ukazany na glebie osobistego doświadczenia mistycznego i talentu ikonografia.
\end{abstract}

Keywords: Jerzy Nowosielski, icon art, contemporary icon, Orthodoxy, sacral image, Polish iconography

Słowa kluczowe: Jerzy Nowosielski, sztuka ikony, współczesna ikona, prawosławie, obraz sakralny, polska ikonografia

Ikona jest we współczesnym chrześcijaństwie zagadnieniem niezwykłej wagi, którego znaczenia w pełni jeszcze sobie nie uświadamiamy. Ponowne odkrycie dla świata ikony na przełomie XIX i XX wieku pozwala nam problem ikony rozpatrywać w różny sposób i w różnych aspektach. Niewątpliwie to właśnie w prawosławiu, ikona jest jednym z zasadniczych elementów prawosławnego kultu, które wypracowało liturgiczny, ściśle określony sposób adoracji ikony, którego źródła kanoniczne i dogmatyczne, sięgają sporu z ikonoklastami i orzeczeń VII Soboru Powszechnego ${ }^{1}$.

W ikonie Kościół prawosławny postrzega nie jakiś jeden aspekt nauczania prawosławnego, a wyraz prawosławia w całości, prawosławia jako takiego. Dlatego nie można zrozumieć ani też wyjaśnić sztuki kościelnej poza Kościołem i jego życiem. Ikona jako obraz święty jest jednym z przejawów Tradycji

Sobór Powszechny w Konstantynopolu w 787 roku. Ostatni wspólny sobór niepodzielonego chrześcijaństwa, na którym został potępiony ikonoklazm (obrazoburstwo), ruch religijny skierowany przeciwko ikonom, mogącym wg inicjatorów wywołać objawy bałwochwalstwa. Na soborze podkreślono, że kult obrazów odnosi się do osoby przedstawionej na obrazie, a nie do samego obrazu jak twierdzili ikonoklaści. kościelnej, na równi z Tradycją zapisaną i Tradycją ustną $^{2}[\ldots]$. Stąd jest zrozumiałe, że poznanie treści

\footnotetext{
Zapis wielką literą słowa „Tradycja” w prawosławnej literaturze teologicznej posiada swoje szczególne uzasadnienie, gdyż w pojmowaniu prawosławnych chrześcijan Tradycja jest czymś bardzo konkretnym. Oznacza mianowicie: księgi Pisma Świętego, Symbol Wiary, postanowienia Soborów Powszechnych i pisma Ojców Kościoła, kanony, księgi liturgiczne i święte ikony - w rzeczywistości jest to cały system nauki, ustroju Kościoła, oddawania czci Bogu, duchowości i sztuki, którym prawosławie od wieków dawało swój wyraz. Współcześni prawosławni uważają się za spadkobierców i strażników bogatego dziedzictwa chrześcijańskiej przeszłości i wierzą, że ich obowiązkiem jest przekazać tę spuściznę w nienaruszonym stanie przyszłym pokoleniom. Zwróćmy uwagę, że część Tradycji stanowi również Pismo Święte. Tradycja definiowana jest niekiedy jako ustny przekaz nauczania Chrystusa, nie zapisany przez Jego najbliższych uczniów. W rzeczywistości istnieje jedno źródło wiary, dlatego Pismo Święte zawiera się w Tradycji i w jej nurcie jest odczytywane. Rozdzielanie i przeciwstawianie ich sobie prowadzi do zubożenia obu tych pojęć. Prawosławne pojmowanie Tradycji nie jest statyczne, lecz dynamiczne, nie jest ślepą akceptacją przeszłości, ale żywym odkrywaniem Boga w teraźniejszości. Choć pozostaje wewnętrznie niezmienna (bowiem Bóg jest niezmienny), Tradycja ciągle przyjmuje nowe formy i postacie, które uzupełniają stare, nie usuwając ich. Szerzej zob. bp. Kallistos Ware, Kościót prawosławny, Bractwo Młodzieży Prawosławnej w Polsce, Białystok, 2002.

Przywołanie tych informacji będzie nam niezbędne w rozważaniach na temat twórczości ikonograficznej Jerzego Nowosielskiego.
} 
i sensu ikony jest przedmiotem teologicznym, podobnie jak poznanie Pisma Świętego. Kościół prawosławny zawsze walczył z zeświecczeniem sztuki sakralnej. Głosem swoich soborów, biskupów i wiernych bronił jej przed przenikaniem obcych elementów, właściwych sztuce świeckiej³

Należy też zauważyć, że we współczesnym świecie wzrasta w widoczny sposób rola ikony i dzisiaj ikona jest problemem kultu już nie tylko dla prawosławia. Również inne wyznania chrześcijańskie, głównie rzymski katolicyzm i anglikanizm, odważnie zaczynają wprowadzać ikonę w obręb swych działań liturgicznych. Sztuka zawsze jest świadectwem epoki, a tym bardziej jest nim ikona jako wcielenie modlitwy. Na początku trzeciego tysiąclecia cały świat chrześcijański podejmuje próby odrodzenia ikony w swoim życiu religijnym. Dla człowieka świeckiej kultury ikona bez wątpienia stanowi wartość estetyczną, lecz jednocześnie wiele współczesnych środowisk chrześcijańskich pyta o jej znaczenie i jej aktualność w żywym doświadczeniu Kościoła. Przed teologami, ikonografiami i historykami sztuki stanęła konieczność przemyślenia na nowo Tradycji ikony. Świat rzuca wyzwanie i chce zrozumieć, ale i odczuć, Tradycję ikony w całej jej głębi. Jedną z odpowiedzi na to wołanie jest ikonografia prof. Jerzego Nowosielskiego. Zwracał on szczególną uwagę na najszerszy krąg promieniowania tego problemu, który wiązał z pojęciem kultu i doświadczenia religijnego.

Wielka aktualność problemu ikony w myśli profesora - to ścisłe związanie zagadnienia ikony z ogólnym stanem nowoczesnej kultury artystycznej. Największe zainteresowanie problemem i, można powiedzieć, największe duchowe zapotrzebowanie na ikonę, tęsknota za nią, istnieje w krajach i środowiskach żywego i wszechstronnego rozwoju kultury plastycznej, w społecznościach, które aktywnie uczestniczą w rozwoju sztuki nowoczesnej ${ }^{4}$. Związek pomiędzy sztuką nowoczesną a zainteresowaniem ikoną w skrócie polega na badawczym charakterze sztuki nowoczesnej jako całości i na analitycznym charakterze jej poszczególnych nurtów, zgłębiających przeróżne dziedziny ludzkiego doświadczenia. Właśnie ta, pogłębiona analiza zjawisk artystycznych, występujących dawniej bardziej spontanicznie i intuicyjnie łączących zespoły działań, daje niejako klucz do nowego rozumienia sztuki odległych epok i kultur. Również po doświadczeniach kubizmu i malarstwa abstrakcyjnego w sposób nieoczekiwany i zdumiewający odżyła dla świata ikona ${ }^{5}$.

Powstaje pytanie - jaka ikona? Słowo ikona oznacza po prostu obraz. W systemie chrześcijańskiej kultury ikona zajmuje unikalne miejsce, dlatego znamy większe znaczenie tego słowa. Bo chrześcijaństwo jest religią słowa - jak stwierdza jedna z największych badaczek ikony Irina

L. Uspienski, Bogostowije ikony w prawostawnoj Cerkwi, Paris 1989, s. 5-6.

J. Nowosielski, Zagubiona bazylika. Refleksje o sztuce i wierze, Wydawnictwo Znak, Kraków 2013, s. 123.

Tamże, s. 123.
Jazykowa - i to określa specyfikę ikony ${ }^{6}$. Kontemplacja ikony nie jest wyłącznie aktem estetycznego zachwytu. Na pierwszym miejscu stoi wspólnota ze Słowem. Kontemplacja ikony to przede wszystkim akt modlitewny, w którym uchwycenie sensu piękna przechodzi w uchwycenie piękna sensu, a w tym procesie człowiek wewnętrzny rośnie, a zewnętrzny maleje. Tego typu związek nie pozwala malarstwu ikonowemu stać się „,sztuką dla sztuki”, do czego ciąży każdy rodzaj artystycznej działalności. Sztuka jest w Kościele nazwana „służebnicą teologii”, ale to nie pomniejsza jej znaczenia, lecz precyzuje jej funkcje $\mathrm{p}^{7}$. A w ogólnym wyczuciu, według słów Jerzego Nowosielskiego, wiąże się ona z pewnym określonym typem obrazu, wyróżniającym się swą tematyką, ale i przede wszystkim swoją specyficzną, tylko sobie właściwą strukturą malarską, wizją plastyczną, sposobem kształtowania efektów kolorystycznych, metodą thumaczenia stosunków przestrzennych i przekładania ich na wartości płaskie. Słowem - swoistą formą artystyczną. Jerzy Nowosielski zaznacza:

Taka ikona powstała w wyniku długiego procesu kształtowania się tej właśnie formy. Proces ten zaczął się jeszcze przed uformowaniem sztuki specyficznie chrześcijańskiej, w łonie sztuki hellenistycznej krajów śródziemnomorskich, przy wielkim udziale określonych elementów filozofii i teologii neoplatońskiej ${ }^{8}$.

Tradycja wczesnochrześcijańska traktuje piękno i sztukę jako jeden z dowodów na istnienie Boga9 ${ }^{9}$. Sztuka wczesnochrześcijańska nawiązuje bezpośrednio do malarstwa występującego w Świątyni Jerozolimskiej i synagogach, oraz późnego antyku. Na ścianach katakumb zachowały się rysunki świadczące o tym, że symbolika biblijna znajdowała swój wyraz w malarstwie i grafice. Stopniowo kultura chrześcijańska przyswajała sobie język antycznej kultury i w miarę jej rozpadu coraz mniej lękano się asymilacji chrześcijaństwa ze światem antycznym. Język późnoantycznej sztuki okazał się przydatny dla chrześcijańskiej sztuki figuratywnej ${ }^{10}$. Można przypuszczać, że malarstwo późnego antyku i malarstwo wzorowane na Świątyni Jerozolimskiej wystarczyło dla półsymbolicznych treści epoki katakumbowej.

W okresie Soboru in Trullo ${ }^{11}$ czysty symbol w malarstwie już nie wystarcza. Ojcowie Soboru w 82 kanonie zalecają, aby zamiast symbolicznego baranka malować postać ludzką Wcielonego Logosu, dla lepszego przyswojenia

\footnotetext{
I. Jazykowa, Świat ikony, przeł. ks. Henryk Paprocki, Wydawnictwo Księży Mariawitów, Warszawa 1998, s. 20.

Tamże, s. 20.

J. Nowosielski, Zagubiona bazylika. Refleksje o sztuce $i$ wierze, s. 123.

I. Jazykowa, Świat ikony, s. 16

Tamże, s. 24

11 Sobór w VII w., jest też nazywany soborem piąto-szóstym, gdyż miał miejsce pomiędzy V i VI Soborem Powszechnym. Uchwały Soboru nie zostały w pełni uznane przez ówczesny patriarchat Rzymu. Jerzy Nowosielski dowodzi, że w świetle rozwoju teologii ikony sobór był bardzo ważnym etapem. Jest to również ważna informacja dla ikonografów tworzących w kręgu współczesnego Kościoła rzymskokatolickiego.
} 
pojęciowego znaczenia oraz głębokości Wcielenia i Odkupienia, a także jej skutków dla rozwoju ludzkiego ${ }^{12}$. Jerzy Nowosielski w prosty sposób przełożył tę terminologię na język nowoczesny, w skrócie oznacza to tyle, że Ojcowie Soboru wzywają do wypracowania formy malarskiej postaci Jezusa Chrystusa, tak by wizja malarska w pelni odpowiadała paradoksalnej treści dogmatu o jedności Osoby i dwoistości natur. Profesor thumaczy to zaistniałą już potrzebą, by na miejsce symbolu dać prawdę psychologiczną, prawdę artystyczną ${ }^{13}$. Jerzy Nowosielski określa to jako etap przygotowawczy $\mathrm{w}$ procesie wprowadzania malarstwa do kultu i życia duchowego. I uważa, że ten moment wyznacza przyszły rozwój ikony i bizantyńskiego kanonu formalnego, który polega na syntezie abstrakcji i realizmu. Ingerencja Ojców Soboru in Trullo dowodzi, że w pewnym momencie zrozumiano, że to co definicja pojęciowa, mogła określić jedynie w sposób negatywny ${ }^{14}$, to wizja malarska jest w stanie pokazać w sposób pozytywny w obrazie. Zrozumiano, że dla wejścia głębiej w tajemnice Wcielenia świat pojęć dyskursywnych nie wystarcza. Odwołano się do świata syntez plastycznych ${ }^{15}$.

Ojcowie VII Soboru Powszechnego, który był ostatnim wspólnym soborem niepodzielonego Kościoła, odrzucili kompromisową propozycję umiarkowanych ikonoklastów. Chcieli oni przyznać malowidłom świętym tę samą cześć, jaką odbierają naczynia liturgiczne. Ojcowie Soboru orzekli natomiast, że malarstwo chrześcijańskie jest integralną częścią żywej Tradycji i nauczania Kościoła, i jako takie jest jednym ze źródeł Objawienia. Dlatego oddaje im się hołd podobnie jak to się czyni przed wizerunkiem Krzyża i Ewangeliami ${ }^{16}$.

Epoka sporów ikonoklastycznych była walką i okresem prześladowania samej idei sztuki sakralnej. Wstrząsnęła ona chrześcijańskim światem w VIII i IX wieku i pozostawiła trwały ślad w historii Kościoła. Echa tego sporu słyszymy do dzisiaj. Dopiero z tego krwawego chrztu wyrasta prawdziwa ikona prawosławna i ona przez wiele stuleci stanowi jedno z najważniejszych doświadczeń charyzmatycznych Kościoła prawosławnego. Ikona, struktura znakowa niosąca informację na poziomie pozawerbalnym, w sposób zasadniczy wpływa na formowanie się liturgii, duchowości Kościoła, na formę ducha modlitwy indywidualnej, kształtuje świadomość duchową i doświadczenie mistyczne zbiorowości.

Sobór Powszechny z 787 roku troszczył się przede wszystkim o dogmatyczną stronę malarstwa ikonowego,

\footnotetext{
12 A. Znosko, ks., Kanony Koscioła prawosławnego, Wydawnictwo Bratczyk, Hajnówka 2000, s. 100.

13 J. Nowosielski, Zagubiona bazylika. Refleksje o sztuce $i$ wierze, s. 109.

14 W Kościele prawosławnym teologia apofatyczna (gr. „negatywny, przeczący”) kładzie nacisk na niewspółmierność wszystkich naszych wysiłków zmierzających do opisania absolutnej tajemnicy Boga. Bóg jako Absolut w sposób nieskończony przekracza wszelkie nasze kategorie. W stosunku do Boga stosuje ona metodę negacji uważając, że same tylko pojęcia nie wystarczają do określenia, kim jest Bóg i go ograniczają.

15 J. Nowosielski, Zagubiona bazylika. Refleksje o sztuce i wierze, s. 109.

16 Dokumenty Soborów Powszechnych. Tekst grecki, laciński i polski, opr. ks. A. Baron, ks. H. Pietras, Tom I, Wydawnictwo WAM - Księża Jezuici, Kraków 2001, s. 339.
}

nie wspomina o artystycznych kryteriach przedstawien, o środkach wyrazu ${ }^{17}$. Dlatego kanon nie jest rozumiany jako zewnętrzne ramy, ograniczające wolność ikonografa, a raczej jako rdzeń dzięki któremu ikona istnieje jako dzieło sztuki. Prawosławna tradycja widzi w ikonie tekst, a nie schemat, co oznacza, że artystyczna strona ikony jest tak samo ważna, jak i jej treść. Nierzadko teolog i artysta jednoczą się w jednej osobie, jak miało to miejsce w wypadku Andrzeja Rublowa lub Teofanesa Greka. Na szczytach swego rozkwitu ikona jednoczyła w sobie ścisłą teologię i wielki artyzm, co pozwoliło Eugeniuszowi Trubieckiemu nazwać ikonę „kolorową kontemplacją"18. Dlatego szczególną uwagę należy zwrócić na analizę samej konstrukcji formalnej i na interpretację związków pomiędzy formą plastyczną $\mathrm{w}$ ścisłym tego słowa znaczeniu a istotą charyzmatycznych treści ikony. Świadomość profesora jest kontynuacją myśli Ojców Kościoła, którzy twierdzili, że w wierności podstawowym zasadom tradycji trzeba się zdobyć na twórczą odwagę. Profesor uważał, że „wielka rzeka życia współczesnego i tradycji powinna pochłonąć poszukiwania naszego czasu, rzucić światło na wszystkie aspekty naszego życia"19.

We współczesnym świecie możemy zaobserwować, że tam gdzie rodzi się przebudzenie, tam pojawia się zainteresowanie ikoną ${ }^{20}$. Jeżeli chcemy podejść poważnie do tematu ikony, to musimy rozważyć jeszcze bardziej rzeczowo samo zjawisko aktualności ikony w życiu Kościoła prawosławnego (nie lokalnego, lecz powszechnego), oraz w życiu innych Kościołów chrześcijańskich, rozważyć je w świadomości religijnej i mistycznej naszego czasu. Rozważyć estetykę i sens duchowy ikony, oraz zrozumieć w czym zawarta jest autentyczna i treść.

W wypowiedziach Jerzego Nowosielskiego odnajdujemy precyzyjne określenie roli środków malarskich w przekazywaniu treści duchowych, tłumaczenie stosunku realistycznych form i działań plastyki do ponadrealistycznej rzeczywistości, będącej przedmiotem obrazowania w ikonie. Odnajdujemy treści, które trafnie, a prosto zarazem, przedstawiają nam duchową zawartość ikony. Profesor zwraca uwage, że warunkiem rozumienia i odczuwania ikony jest przekroczenie pewnego minimum kultury plastycznej ${ }^{21}$. Jerzy Nowosielski podkreślał, że taki stan nie koniecznie musi być związany ze stopniem wykształcenia

\footnotetext{
17 Tamże, s. 337.

18 E. Trubieckoj, Kolorowa kontemplacja. Trzy szkice o ikonie ruskiej, przeł. ks. Henryk Paprocki, Bractwo Młodzieży Prawosławnej, Białystok 1998.

19 J. Nowosielski, Zagubiona bazylika. Refleksje o sztuce i wierze, s. 124. 20 W Polsce w ciągu ostatnich lat można zauważyć rosnące zainteresowanie ikoną. Świadczy o tym działalność coraz większej liczby prawosławnych ikonografów. Wieloletnia działalność studium ikonograficznego w Bilesku Podlaskim prowadzonego przez ks. Leoncjusza Tofiluka pozwoliła wykształcić wielu specjalistów z tej dziedziny. Pojawili się również pierwsi malarze ikon w Kościele rzymskokatolickim. Ciekawą propozycją środowiska prawosławnego i rzymskokatolickiego jest „Akademia Ikony" w Warszawie działająca od 2012 r. zorganizowana prze Muzeum Ikon i Studium Ikonograficzne, pracownię św. Andrzeja Apostoła.

21 J. Nowosielski, Zagubiona bazylika. Refleksje o sztuce i wierze, s. 126.
} 
artystycznego czy oczytania w przedmiocie. Oto fragment jednej z wypowiedzi artysty:

Znam ludzi prostych, u których zaskoczył mnie niesłychanie żywy i autentyczny odbiór działania malarstwa, nawet jego poszczególnych, oderwanych elementów. Co więcej, nie tylko w sposób ogólnikowy potrafili oni o swoich reakcjach dać poznać, ale potrafili poszczególne stadia swego przeżycia opowiedzieć beż żadnej mglistej egzaltacji, ściśle i nad wszelką wątpliwość wiarygodnie.

Znam też innych, z wyższym wykształceniem humanistycznym, erudytów, w sprawach związanych $\mathrm{z}$ teorią i historią sztuki, absolutnie głuchych i ślepych na najprostsze bodźce plastyczne. Jak możliwa jest taka sytuacja? ${ }^{22}$

Profesor odpowiedzi na możność autentycznego przeżycia $\mathrm{w}$ odbiorze dzieła malarskiego doszukiwał się w dyspozycjach psychicznych. Uważał, że zależy ona od określonego stanu duchowego, poprzedzonego okresem sprzeciwu wewnętrznego. Charakteryzującego się postawą wybitnie negatywną, z ujemną reakcją na wszelkie bodźce plastyczne. Szczególne aktywne są wtedy wszelkie mechanizmy krytycznej oceny i wartościowania. Ludzie przeżywający takie stadium rozwoju swojej świadomości w ocenach estetycznych wydają sądy prawidłowo opatrzne. Może nastąpić też rewolucja ocen i kryteriów, dojrzałość plastyczna. Nowoczesna psychologia ${ }^{23}$ doskonale zna tego rodzaju zjawiska „nawrócenia”, odwrócenia niejako perspektywy co w chrześcijańskim doświadczeniu wiąże się z pojęciem żalu, pokutnego nawrócenia. ${ }^{24}$

Profesor zwracał niezwykłą uwagę na pierwszy krok nawiązania bezpośredniego i autentycznego kontaktu ze sferą działań plastycznych. Krok ten jest niezmiernie ważny, bowiem stanowi on nieomylną oznakę przezwyciężenia pewnego typu „naiwnego racjonalizmu” świadomości wzrokowej25. Ten „naiwny racjonalizm” świadomości wzrokowej według profesora jest ważnym elementem ogólnej postawy psychicznej. Zjawisku temu krańcowo przeciwstawia kontemplacyjny stosunek do działań plastycznych.

Jak postawę „naiwnego racjonalizmu” cechuje przewaga rezonerstwa, sprawdzania poszczególnych doznań z góry przyjętymi schematami myślowymi, ustawiczna cenzura bodźców i własnych na nie reakcji, a więc sprawdzanie prostego procesu postrzegania - odbierania do tego stanu ciągłego śledztwa

\footnotetext{
22 Tamże, s. 126.

23 Artysta mówi tu o psychologii głębi - termin określa różne koncepcje psychologiczne, które stanowią teoretyczne zaplecze dla różnych form psychoterapii (niekoniecznie psychoanalitycznych). Wspólnym elementem różnych szkół psychologii głębi są kategorie podświadomości oraz nieświadomości oraz założenie, że są to sfery ludzkiej psychiki znajdujące się w ukryciu.

24 J. Nowosielski, Zagubiona bazylika. Refleksje o sztuce $i$ wierze, s. $126-127$.

25 Tamże, s. 127.
}

i porównywania, tak postawę kontemplacyjną cechuje spokojne poddanie się działaniu przedmiotu postrzegania, utożsamianie elementów naszej świadomości z elementami działania malarskiego ${ }^{26}$.

Jerzy Nowosielski zwracał uwagę na fakt, że byliśmy świadkami epok, w których nie wierzono, by ktoś poza samym malarzem potrafił przeżywać istotne wartości malarstwa. Przyjmując jednak, że ze sztuką jest zupełnie inaczej, że malarskie działania mogą być nośnikiem konkretnych prawd i tajemnych procesów, to dochodzimy do niezwykle ważnego wniosku: sztuce, a szczególnie malarstwu, przypada niezastąpiona rola formowania i wywoływania określonych stanów świadomości ponaddyskursywnej, pokrewnej, a może niekiedy identycznej z przeżyciem mistycznym już w skali odbioru zbiorowego społeczności religijnej ${ }^{27}$.

W okresie ogólnego zwątpienia w tajemnicę, w charyzmat liturgiczny naszej epoki, w czasie kiedy widzimy wyjałowienie ze wszelkich działań o charakterze inicjatywy w stosunku do wyższej świadomości. Jest zauważalne, że właśnie za pomocą sztuki, podobnie jak w innych epokach życia Kościoła, jesteśmy w stanie budować wspólną świadomość ponaddyskursywną i wspólne przeżycie mistyczne. Tę myśl Jerzego Nowosielskiego świetnie konkluduje jego wieloletni przyjaciel, prawosławny duchowny ks. Henryk Paprocki:

Wśród rozlicznych bowiem dialogów teologicznych, toczących się we współczesnym świecie, jedynie kilka może mieć przyszłość. Wydaje się, że są to przede wszystkim dialog Kościoła prawosławnego z Kosciołami przedchalcedońskimi oraz Kościoła prawosławnego z Kościołem rzymskokatolickim. Te właśnie Kościoły odwołują się do Tradycji i poszukują możliwości powrotu do Tradycji niepodzielonego Kościoła. Wszelki dialog wtedy jest owocny, kiedy następuje autentyczna wymiana myśli [...]. Nie trzeba wyjaśniać czym ikona jest dla prawosławia oraz czym może być dokonujące się na naszych oczach odkrycie ikony przez inne Kościoły. W czasach kryzysu sztuki, zwłaszcza sztuki figuratywnej, ikona i związana z nią teologia, otwierają nowe możliwości rozwoju myśli teologicznej, modlitwy i kontemplacji28.

Sztuka charyzmatyczna w życiu Kościoła prawosławnego, sztuka ikony przede wszystkim, mimo, że formalnie zachowuje ważne miejsce w rzeczywistym odbiorze jej prawdziwych i istotnych elementów, wegetuje na zasadzie archeologicznego reliktu. Albo z powodu zupełnego jej niezrozumienia staje się skostniała. Jak to wyraził patriarcha Atenogoras ${ }^{29}-\mathrm{z}$ ikoną sprawa ma się tak samo jak

\footnotetext{
26 Tamże, s. 127.

27 Tamże, s. 127-128

28 I. Jazykowa, Świat ikony, s. 202, Myśl thumacza zawarta w posłowiu.

29 Prawosławny patriarcha Konstantynopola Atenagoras. Wraz z papieżem rzymskokatolickim Pawłem VI w 1965 zdjęli z siebie ekskomuniki i rozpoczęli dialog teologiczny.
} 
z myślą Ojców. Pozostając całkowicie oddanym Tradycji i podstawowym kanonom świętej sztuki, trzeba ośmielić się tworzyć tę sztukę. Inaczej nie wyjdziemy poza pobożną archeologię. Główny nurt życia Tradycji powinien wchłonąć w siebie poszukiwania naszych czasów, oświecić życie we wszystkich jego aspektach..." ${ }^{30}$ Marzymy o sztuce odnoszącej się do Praobrazu, której jesteśmy pozbawieni - pisał W. Komarowski.

Wiedza, którą daje rzemiosło ikonograficzne, jest potrzebna i pożyteczna, ale nie ma co się łudzić nadzieją, że tędy wiedzie droga do ikonografii. Dobrze malować ikony z dawnych ikon - to już wielka rzecz, tu konieczny jest talent i smak, niedostępne współczesnym rzemieślnikom-ikonografom. Wykonanie dobrej kopii, ale nie imitacji, to już zadanie dla ikonografia-artysty. Jednak by przygotować drogę twórczej ikonografii, potrzeba czegoś innego: znajomości praw formy plastycznej ponieważ w swojej istocie taka jest forma ikonograficzna. Nauczenie się tych praw jest niemal niemożliwe. Można jedynie uświadomić je sobie, lub starać się z nimi zapoznać. W sumie jest to niemal sytuacja bez wyjścia, ale przecież dzieło, które wykonujemy, jest po części cudem. Wszelki wysiłek w tym kierunku jest cenny, konieczny. Natomiast namiastka ikonografii dająca iluzoryczny posmak klasycznego stylu, jest fałszywa i szkodliwa. Niech ikonografia będzie uboga, ale prawdziwa. Nie możemy nie dążyć do formy, jak i nie możemy zrezygnować $\mathrm{z}$ dążenia do poznania Praobrazu. ${ }^{31}$

Jak wynika $\mathrm{z}$ wypowiedzi artysty, Nowosielski realizuje swoje ikony w oparciu o kanon, który jest pewną dyscyplinująca zasadą, która pozwala na ujawnianie świata ponadrzeczywistego w obrazach sztuki. Określa treść, sposób widzenia określonych typów, jak i traktowania przedstawień - ich symboliki i kształtów. Nie jest on wyłącznie zewnętrzną zasadą, kategorycznego prawa obligującego do pasywnego kopiowania. Ikona oznacza artystyczne powielanie, ale nie kopiowanie. Jest to znajdowanie wspótczesnymi środkami $i$ we wspótczesnej świadomości tego, co mistrz raz już znalaz ${ }^{32}$. Treść ikony także nie może być uważana za wyczerpaną, niedopuszczającą zmian czy też rozwoju. Wystarczy wskazać fakt, ze kanonizacje poszerzają grono świętych, pojawiają się także cudowne ikony: dotychczas nie znane i o nowej treści ${ }^{33}$. Życie Kościoła pisze Bułhakow - nigdy nie wyczerpuje sie przeszłościa, ma teraźniejszość i przyszłość, zawsze będac kierowanym przez Ducha Świętego, jeśli duchowe wizje i objawienia, zaświadczone na ikonach możliwe byty dawno temu, to sa one możliwe teraz $i$ w przyszłośs $i^{34}$.

\footnotetext{
30 Tamże, s. 199-200.

31 W. Komarowski, Pismo ob. Ikonopisi, [w:] Prawosławnaja ikona.

Kanon i stil, Moskwa 1998, s. 158-160.

32 S. Bułhakow, Ikona i kult ikony, Bydgoszcz 2002, s. 65.

33 Tamże, s. 66.

34 Tamże.
}

Kanon jest zatem normą, która działa na mocy swej siły dowodowej. Nie zewnętrzno-rzemieślnicze, a artystyczno-religijne wykonanie jest automatycznie twórczą percepcją. Kanon żyje twórczo, nieustannie odnawia się $\mathrm{i}$ tak wzbogaca $\mathrm{w}$ ikonie, zatem ona sama nie jest prawem, lecz soborowym widzeniem, w które włącza się każdy członek prawosławnego kościoła, mający twórcze, lecz nie samowolne podejście do kanonu. $\mathrm{Z}$ drobnych tych zmian powstają nowe oryginały i tak realizuje się życie tradycji w kanonie ikonograficznym ${ }^{35}$. Duch Święty nie udziela Swoich darów wedle jakiejś miary, fakt ten nie oznacza jednak, że dopuszczalne jest wymyślanie ikon poza związkiem z tradycją. Nowość w sztuce powinna być owocem kontemplacji oraz twórczo uzasadnionej wizji artystycznej. Nie może być sprawą alegoryzmu lub rzemiosła, a jedynie połączeniem religijnego oświecenia oraz artystycznego natchnienia ${ }^{36}$. Kanon w ikonie nie jest rozumiany jako zewnętrzne ramy, ale jako rdzeń, dzięki któremu ikona istnieje jako dzieło sztuki - tekst wiary Kościoła ukazany na glebie osobistego doświadczenia mistycznego i talentu ikonografia ${ }^{37}$. Jakkolwiek obowiązujący, pozwala na zmianę rytmu kompozycji, rozkładu barw oraz na zaistnienie tych szczegółów, które nadają dziełu charakter oryginal$n{ }^{38}$. Kanon jest gwarancją autentyczności sztuki. Zabezpiecza ja i chroni ją formalnie ${ }^{39}$. Nie wystarczą pobożne uczucia, aby uczynić formę artystyczną formą sakralną. Sztuka staje się sakralną, gdy w jej formy zostaje wcielona wizja duchowa ${ }^{40}$. Ten właśnie element powoduje, że ikona zaczyna emanować sacrum.

Przytoczone tutaj wypowiedzi i analizy to tylko niektóre z tych, jakie możemy odnieść do twórczości Jerzego Nowosielskiego. Fenomen malarstwa Nowosielskiego należy do najczęściej komentowanych na gruncie współczesnej sztuki polskiej zagadnień. Jego odwaga zadziwia, ponieważ tworzył on w skomplikowanych warunkach i środowisku raczej nieskłonnym do poszukiwań. Dążąc do odrodzenia ikonografii nigdy nie wykonywał obojętnych kopii. Jego malarstwo wynika z żywego doświadczenia tradycji, przyswojenia kanonu w głębi serca. W średniowiecznym życiu Kościoła ten dar był powszechny, stał się jednak rzadkością. Dar tworzenia i dar przyjmowania malarstwa świętego - ikony. Bo ikona jest również obrazem naszej wiary, więc jacy my jesteśmy, taka jeż też ikona. Trzeba przyznać, że prace Jerzego Nowosielskiego wychodzą poza ramy przyzwyczajenia, ale będąc obiektywnym, należy też uznać, że piękno estetyczne dzieł Nowosielskiego jest sprawą niekwestionowaną, chociaż nie wszyscy muszą je odbierać w ten sam sposób. Nie ono jednak jest przedmiotem niniejszych rozważań - są nim dociekania na temat piękna transcedentalnego i żywego udziału współczesnego artysty $\mathrm{w}$ procesie twórczym obrazu sakralnego - ikony.

\footnotetext{
35 Tamże, s. 67

36 Tamże, s. 88

37 I. Jazykowa, Świat ikony, s. 20.

38 P. Evdokimov, Sztuka ikony. Teologia piękna, Warszawa 1999, s. 184.

39 M. Quenot, Ikona. Okno ku wieczności., Białystok 1997, s. 58

40 Tamże, s. 68.
} 


\section{Bibliografia}

Bułhakow S., Ikona i kult ikony, Bydgoszcz 2002.

Dokumenty Soborów Powszechnych. Tekst grecki, taciński i polski, opr. ks. A. Baron, ks. H. Pietras, Tom I, Kraków 2001.

Evdokimov P., Sztuka ikony. Teologia piękna, przekł. M. Żurowska, Warszawa 1999.

Jazykowa I., Świat ikony, przeł. ks. Henryk Paprocki, Warszawa 1998.

Komarowski W., Pismo ob. Ikonopisi, [w:] Prawosławnaja ikona. Kanon i stil, Moskwa 1998.
Nowosielski J., Zagubiona bazylika. Refleksje o sztuce $i$ wierze, Kraków 2013.

Quenot M., Ikona. Okno ku wieczności, przekł. H. Paprocki, Białystok 1997.

Trubieckoj E., Kolorowa kontemplacja. Trzy szkice o ikonie ruskiej, przekł. H. Paprocki, Białystok 1998.

Uspienski L., Bogosłowije ikony w prawosławnoj Cerkwi, Paris 1989.

Znosko A., ks., Kanony Koscioła prawosławnego, Hajnówka 2000.

Rozmiar artykułu: 0,6 arkusza wydawniczego 
ISSN 1508-7719

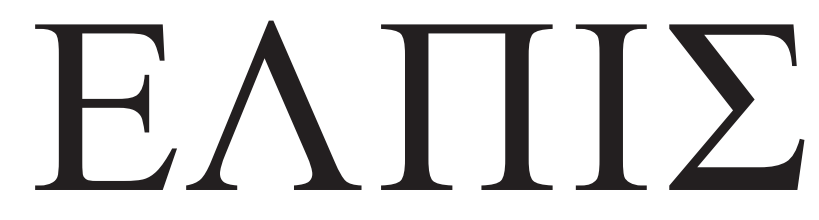

CZASOPISMO TEOLOGICZNE KATEDRY TEOLOGII PRAWOSŁAWNEJ UNIWERSYTETU W BIAŁYMSTOKU

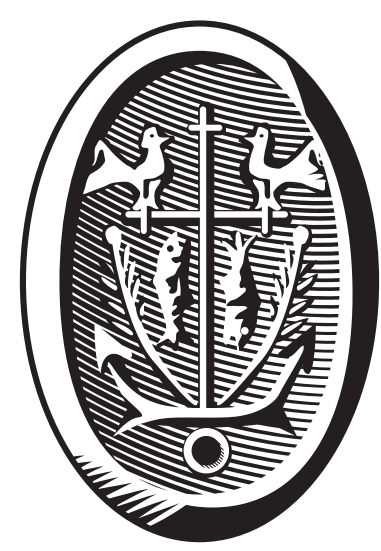

ADRES REDAKCJI

15-097 Białystok, ul. M. Skłodowskiej-Curie 14 tel. 85 745-77-80, e-mail: redakcja@elpis.edu.pl www.elpis.uwb.edu.pl 